\title{
Contents of the Handbook
}

\section{VOLUME I TRADITIONAL \\ TELECOMMUNICATIONS NETWORKS}

Preface

Gary Madden

1. On the subadditivity of cost functions

Russel J. Cooper, W. Erwin Diewert and Terence J. Wales

2. Cost function issues and estimation

Yale M. Braunstein and Grant Coble-Neal

3. Telecommunications productivity

Laurits R. Christensen, Philip E. Schoech and Mark E. Meitzen

4. Competition in local and long-distance telecommunications markets T. Randolph Beard and George S. Ford

5. Telecommunications demand Lester D. Taylor

6. Retail telecommunications pricing in the presence of external effects Benjamin E. Hermalin and Michael L. Katz

7. Vertical integration in telecommunications Dennis L. Weisman

8. Global competition in telecommunications Douglas A. Galbi

9. US settlement reform: an historic review Michael A. Einhorn

10. Telecommunications infrastructure and economic development M. Ishaq Nadiri and Banani Nandi

11. Universal service

James H. Alleman and Paul N. Rappoport 


\section{VOLUME II EMERGING TELECOMMUNICATIONS NETWORKS}

1. Innovation in advanced telecommunications networks Cristiano Antonelli

2. Economics of the Internet Michael D. Pelcovits and Vinton G. Cerf

3. Residential demand for access to the Internet Paul N. Rappoport, Donald J. Kridel, Lester D. Taylor, James H. Alleman and Kevin T. Duffy-Deno

4. Electronic commerce and industrial organization Steven Globerman

5. The economics of online retail markets Michael R. Ward

6. Regulation for Internet-mediated communication and commerce Robert M. Frieden

7. Product bundling and wholesale pricing Timothy J. Tardiff

8. Mobile telecommunications and regulatory frameworks Harald Gruber and Tommaso M. Valletti

9. Satellite communications services Joseph N. Pelton

10. Regulated costs and prices in telecommunications Jerry A. Hausman

11. Universal service in the information age Jorge Reina Schement and Scott C. Forbes

\section{VOLUME III WORLD TELECOMMUNICATIONS MARKETS}

1. Corporate and regulatory strategy for the new network century Eli M. Noam

\section{Part 1 From Telecommunications Reform to Information Social Policy}

2. Evolution of the telecommunications industry Martin Fransman 
3. Preparing the information infrastructure for the network economy William H. Melody

4. Telecommunications policy research in information society discourse Erik Bohlin

\section{Part 2 Corporate Experience and Visions}

5. Formation and development of international alliances Peter Curwen

6. BT corporate experience and visions, 1990-2000 Niall Levine, Douglas Pitt and David Lal

7. The evolution of US WEST and MediaOne Martin G. Taschdjian

8. Sprint-GTE's lost opportunity James H. Alleman and Lawrence Cole

\section{Part 3 International Cooperation and Coordination}

9. The European Union and world telecommunications markets Richard Cawley

10. The FCC and policy federalism: broadband Internet access regulation Timothy Brennan

11. International telecommunication regulation: a trophy or atrophy Tim Kelly

12. The OECD and the internationalization of telecommunications Dimitri Ypsilanti

13. International efforts to bridge the digital divide: a global imperative Bruno Lanvin

14. World Bank telecommunication sector activity: the 1990s and beyond Charles Kenny

15. Telecommunications in the multi-lateral trading system Claude E. Barfield and Steven Anderson 


\section{Part 4 Regional Developments}

16. Regulation of Internet services in North Africa Andrea L. Kavanaugh

17. Organizational change in Australasian telecommunications companies Mark A. Shadur, Kellie Caught and René Kienzle

18. Brazilian telecommunications: experience and future perspectives Marcelo Resende

19. China leaps into the millennium Meheroo Jussawalla

20. Regulation of French telecommunications and electricity markets Nicolas Curien and Dominique Bureau

21. Sector-specific regulation of German telecommunications Günter Knieps

22. Challenges for Indian telecommunications: the 1990s and beyond T.H. Chowdary

23. Making markets: telecommunications in Western Europe Willem Hulsink and Andrew Davies 